\title{
DỨBin
}

Technological University Dublin ARROW@TU Dublin

\section{How Journalism Became a Profession}

\author{
Michael Foley \\ Technological University Dublin, michael.foley@tudublin.ie
}

Follow this and additional works at: https://arrow.tudublin.ie/aaschmedbk

Part of the Arts and Humanities Commons

\section{Recommended Citation}

Foley, M.: How Journalism Became a Profession. In Irish Journalism Before Independence, Rafter, Kevin, (ed), (2011) Manchester University Press.

This Book Chapter is brought to you for free and open access by the School of Media at ARROW@TU Dublin. It has been accepted for inclusion in Books/Book chapters by an authorized administrator of ARROW@TU Dublin.

For more information, please contact arrow.admin@tudublin.ie, aisling.coyne@tudublin.ie, gerard.connolly@tudublin.ie.

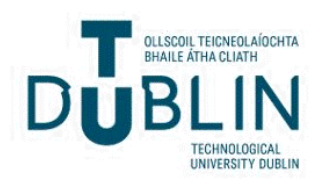




\title{
How journalism became a profession
}

\author{
Michael Foley
}

It was not inevitable that in 1922 Ireland would emerge from more than a century of political and social struggles as a democracy, but it did for many and complex reasons, one of which was the press and how it evolved throughout the nineteenth century. Understanding how the press and journalism developed tells a lot about social development in Ireland, and also sheds light on a media that came of age in a colonial context that was very different from journalism in the two other main English speaking countries, Britain and the United States.

As part of the United Kingdom since the Act of Union in 1801, Irish journalists and editors were, of course, integral to debates surrounding freedom of expression and liberty of the press that had been part of British intellectual discourse since Milton. There was also another intellectual stream in Ireland, which derived from the republican ideals of the French Revolution, the Rights of Man, and the right to freedom of thought and opinion. Despite such debates, however, the British authorities entertained reluctantly the notion of a free press within Britain and, especially, Ireland. Thus an increasingly professionalised journalism developed in Ireland in the context of a struggling public sphere and a political partisan press, which was ironically often politically engaged. All these factors had a profound affect on how independence developed in the new century.

Journalism, to appropriate Jean Chalaby's term, was an 'invention' of the Victorian era, and while there are many similarities between the journalistic cultures of the two islands, there are also significant differences. ${ }^{1}$ The similarities are all the more evident when one recalls the many highly influential Irish journalists, such as William Howard Russell, James J. O'Kelly and T. P. O'Connor, who worked in Britain. Irish journalism was, however, influenced by much more than the journalism of London. Historically, not only had Irish journalists worked in North America and Australia, but many worked as foreign correspondents in far-flung corners of the Empire for British newspapers. All these factors, geographical and 
ideological, influenced how journalism developed as a professional practice in Ireland at a time of seismic change.

The nineteenth century opened with the Act of Union, followed by a series of major, often dramatic political and economic developments: Catholic Emancipation which allowed Catholics to take their seats at Westminster; the Repeal movement which sought the restoration of a local parliament in Dublin; the Famine of the 1840s; the Land War; the rise of both militant and constitutional nationalism; the political debates surrounding Home Rule; the struggles of the Irish Parliamentary Party at Westminster; and the rise and fall of Charles Stewart Parnell; the War of Independence; and, in 1922, Irish independence itself followed by the trauma of civil war. Journalists in Ireland worked as professional recorders of these events, working for a politicised press and a tradition of political engagement into the twentieth century, not unlike journalism in Europe. Given the political and social conditions in Ireland it was inevitable that journalism and the press would evolve both at a different rate and in a different direction to that of Britain which was, from the 1850 s onwards, an increasingly commercial press, whose development is trenchantly analysed by James Curran and Jean Seaton in their pioneering work on the British media, Power Without Responsibility. ${ }^{2}$ In Ireland colonial conditions and the state of Irish capitalism delayed many of the economic developments within the media that took place in Britain. ${ }^{3}$

But it was not just political turmoil that underpinned the development of journalism in Ireland, there were other social factors as well: the establishment of the national school system and the growth in literacy; the abolition of stamp duty; changes in print technology; improved transport; growth of urbanisation following the famine; improving telegraphy; and increasing advertising revenue were the major factors in what Raymond Williams has called the 'long revolution'.

In Ireland, even the most humble journalists reported on historic events, often at some danger to themselves. Andrew Dunlop - whose memoir of his time in Irish journalism from the 1860 s to the early years of the twentieth century provides a rare and invaluable source of journalistic practice in this era - gives an account of covering an eviction and the risk of being mistaken for a pernicious process server who delivered the eviction notice.

It was the practice at the time to bring down special bailiffs from Dublin, men who were not known in the locality, so that the identity of the process server might be more difficult to ascertain. One result of this, however, was that any civilian who was a stranger ran a risk of being mistaken for a process server. ${ }^{4}$

The illustrated newspapers made much pictorial mileage out of these events. Towards the end of the Land War, the Illustrated London News, for instance, thought it worth recording the treatment of one of its Special Artists in 
Ireland showing him being drummed out of an Irish town by a crowd brandishing sticks, who had probably mistaken him for a process server. The dangerous situation was uncharacteristically understated in its caption: 'Our Special Correspondent Misunderstood by the Crowd'. ${ }^{5}$

Increasing sectarianism in Northern Ireland, especially in Belfast, offered further differences between the working experiences of Irish journalists compared to their British colleagues. For Irish journalists covering political events, sectarian violence and riots were part of the job. The reaction of a visiting journalist from England, F. Frankfort Moore, is interesting in that he was evidently shocked at the experiences of his Irish colleagues. Moore was so taken aback at the risk of working as a reporter in Belfast in the 1880s that he suggested they be paid danger money. As he put it himself:

I chanced to be in Belfast at the time of the riots in 1886, and in my experience of the incidents of every day and every night led me to believe that British troops have been engaged in some campaigns that were a good deal less risky to the war correspondents than the riots were to the local newspaper reporters. Six of them were more or less severely wounded in the course of a week. I am strongly of the opinion that the reporters should have been paid at the ration of war correspondents at that time. ${ }^{6}$

\section{Catholic emancipation, repeal and the creation of a public sphere}

The journalist taking a shorthand note at a public meeting was, in effect, facilitating the development of a public sphere within which political debates took place. From the end of the eighteenth century right up into the twentieth century, campaigns for political and social change were often linked with newspapers and other forms of journalism. Additionally, the protagonists were often themselves political activists, Members of Parliament or members of revolutionary organisations. As Joep Leerson explains:

Printing was revolutionised by the invention of the rotary press in 1811; paper manufacture likewise by the invention of mechanised paper production in the 1790s and the introduction of wood pulp as an ingredient. As a result the production costs of printed matter plummeted in the decades following 1810 - that is to say, precisely at the time when Catholic Emancipation redefined the accessibility and distribution of Ireland's public space and public sphere. ${ }^{7}$

The winning of Catholic Emancipation in 1829 was a constitutional revolution achieved by mobilising public opinion. The Catholic Association, established by O'Connell was a mass-movement, funded by the so-called 
'Catholic Rent', the penny-a-month subscribed by thousands of people around the country. By the 1820s, the Catholic gentry - of which O'Connell was a member - together with commercial interests in the towns, had evolved a 'liberal Catholic' politics; as Roy Foster explains, O’Connell's lieutenants, 'prosperous farmers, businessmen, the urban merchant community and newspaper editors were much in evidence.8

O'Connell's own understanding of the press's role is evident in his grasp of the part played by editors in campaigns for Catholic Emancipation and, later, the Repeal Movement. The extent to which O'Connell advocated the development of the press and used it to his political advantage is striking, The Cork Examiner, for example, founded in 1841, actively supported O'Connell. The newspaper was first published by John Francis Maguire, who was an MP and supporter of O'Connell in the House of Commons. The example of Maurice Lenihan is also instructive. He was the sort of middle class Catholic who was the backbone of the Catholic Association. Lenihan worked for a number of Munster newspapers, before being urged by O'Connell to start a newspaper in Nenagh, Co. Tipperary, advocating repeal. O'Connell himself announced the founding of the Tipperary Vindicator in $1844 .^{9}$

It would be a mistake to view the development of the press in Ireland, and with it journalistic practice, as one forward move towards greater freedom and influence. The attitudes of British governments towards issues such as press freedom might have been changing slowly in Britain, but in Ireland, the authorities were still highly reluctant to entertain any move toward press freedom, and harassment and repressive legislation was used against the press throughout this period. By 1880, most newspapers, both Dublin dailies and the weekly provincial newspapers, were identified politically. About one third of the provincial newspapers had declared themselves as nationalist. This brought with it popularity in terms of readership, but their association with movements, such as Repeal, the Land League and other reform movements, meant the same newspapers were victims of the legislation to close newspapers, destroy printing presses and arrest proprietors for printing what was claimed as seditious material.

In Dublin, there was the moderately liberal, Dublin Evening Post, the conservative Dublin Evening Mail and, from 1859, the liberal unionist, Irish Times. The two most influential newspapers were, however, The Nation and the Freeman's Journal, two nationalist newspapers. The Nation was the paper of Young Ireland, a movement that resembled European romantic nationalist movements, such as Mazzini's Young Italy. The Nation achieved a readership possibly as high as 250,000 by 1843 . Due to its availability in reading rooms, its actual circulation would, of course, have been considerably less. The Freeman's Journal was the most influential nationalist newspaper up until the 1890s. Its support for Home Rule was such, that by the 1890s, it was almost considered the official organ of the Irish Parliamentary Party, with 
Home Rule and land reform the only issues considered of any importance editorially. Bill Kissane argues in Explaining Irish Democracy that a civil society developed in nineteenth century Ireland, which had profound implications for the development of Irish politics:

If civil society is a sphere in which democratic practices can develop, in which an autonomous public opinion can be formed, and in which people acquire the skills that make them effective citizens in a modern polity, then the development of Irish civil society should be regarded as a precondition of the emergence of Irish democracy between 1918 and $1922 .{ }^{10}$

Kissane does not include journalism or the media in his analysis, other than mentioning the Institute of Journalists as one of the organisations beginning to regulate professional life in the second half of the nineteenth century. But there is little doubt that the press and journalists were involved in the development of this civil society, with newspapers reporting on activities of the many civic, community, professional, self-help, political, cultural and other organisations, which, Kissane argues, were the foundations of Irish civil society. Journalists were in the forefront of creating an autonomous public opinion that was necessary for the development of democratic practice.

A major factor in the growth of newspapers was, of course, the political situation in Ireland. Political events and the role of newspapers in expressing popular viewpoints allowed some to flourish, but others, failing to read public opinion accurately or holding political viewpoints that had fallen out of favour, just disappeared. As John Horgan sees it:

It was a journalistic landscape which had evolved dramatically in the second half of the nineteenth century, as the old network of small Protestant owned papers, situated for the most part in garrison towns was supplemented, challenged and in some cases obliterated by the growth of nationalist papers whose success was based partly on rising education and income levels among the Catholic population, and partly on developing forms of political self expression from the Land War in the 1880 s onwards. ${ }^{11}$

The Nation itself grew out of a split within the Repeal Movement. Other publications were associated, or became associated, with particular political organisations, such as the Freeman's Journal and the Irish Parliamentary Party and Parnell. Unionist newspapers including The Irish Times voiced the other viewpoint in Ireland, that of defence of the Union and the link with Great Britain. 


\section{Professional journalists and journalistic practices}

So who were these Irish journalists? According to British sources, such as the novelist William Thackeray in his novel Pendennis, they were lovable rogues, hard drinking hacks, but dishonest and not to be trusted. ${ }^{12}$ The reality was somewhat different. What emerges from memoirs and other accounts is of journalists coming from the emerging urban middle classes, especially the Catholic middle classes. Journalism offered paid employment for young men whose background did not include a private income, and who could not necessarily attend for religious reasons the country's only university, Trinity College, Dublin. ${ }^{13}$ For young men who were politically aware and interested in parliamentary politics journalism was an ideal occupation. As Legg notes: 'Journalism was a respectable profession unconnected with the problems of land ownership and the governing powers. ${ }^{14}$ Far from being the hacks of English prejudice, many Irish journalists were idealistic men who saw in journalism a respectable way of influencing events. Commenting on the role and place of the journalist in Irish society towards the end of the nineteenth and early twentieth century, Declan Kiberd, compares the distinction made in Britain between the journalist and the artist or literary writer. He suggests that the chasm between the two that exists in many cultures did not so exist in Ireland.

The major debates of the Irish revival were conducted in the pages of the Daily Express and United Irishman. Contributing journalists belonged to a profession for which a university degree was not a prerequisite, which accounts for the democratic tone and suspicion of aristocracy in these exchanges. Many supported movements for 'self-help', whether in adult education or Abbey Theatre, on principles first laid down by Jonathan Swift. He had shown in his brilliant polemics that it was quite possible to close the gap between journalism and art. ${ }^{15}$

Mathew Bodkin was one such boy who became a journalist and later a barrister and then an MP. Bodkin worked for the Freeman's Journal, while reading for the Bar, a route to a professional qualification popular among middle class Catholics. 'While learning law and eating dinners I contrived by the influence of Bishop Duggan to get a place as an unpaid probationer on the reporting staff of the Freeman's Journal.' ${ }^{\prime 6}$ The legendary journalist and Member of Parliament, T. P. O'Connor, ${ }^{17}$ who worked for Saunder's Newsletter in Dublin, the Telegraph in London and founded the Star, the Sun and T. P.'s Weekly, learnt shorthand in Galway, while attending Queen's College, Galway. In his biography of O'Connor, Henry Hamilton Fyfe gives an account of the attractions of journalism for a boy of a particular class:

The expense (unavoidable at that time) of going to London to 'eat his 
dinners' - that is to keep his terms at an Inn of Court - put an end to this dream of becoming a barrister. His hopes of a Civil Servant appointment were as effectively blasted. He looked around and saw that in Ireland then 'there was always a good deal of what is called official note-taking - that is to say, the reporting of governmental commissions, of state trials and the like'. The shorthand reporters who did this were paid at the rate of eight pence for every seventy-two words. During the latter part of his attendance at Queen's College O'Connor had been learning shorthand. ${ }^{18}$

Following graduation O'Connor was employed as a reporter on Saunder's Newsletter, which he described as a 'good old stout State and Church full-blown Protestant organ', at a salary of two pounds a week. ${ }^{19}$

While the Irish press remained a political press long after the English press had become more or less wholly commercial, journalists themselves had absorbed ideas that we can now see as an emerging professional identity. Accuracy, of necessity, was a major factor in the professionalisation of journalism. The use of criminal libel, defamation, and the need to cover highly controversial political trials encouraged the use of shorthand to ensure accuracy. In his novel, White Magic, Bodkin, gives an account of a young man seeking a post in a fictitious Dublin newspaper, the Free Press, obviously a thinly disguised Freeman's Journal. It is clear from this account that for all his accomplishments, including attending one of Ireland's foremost boys' schools, the editor is seeking skill in shorthand:

'What can you do?' said Grayle shortly, with an abrupt change of manner. ${ }^{20}$

'Very little, I'm afraid,' said Gerald shyly. He had not he <<the???>> faintest notion what he might be expected to do.

'He took first place at Clongowes,' broke in Dr Burton. 'He was their best all round boy at books and games, and the captain of the eleven.'

Grayle smiled.

'Have you ever written anything?'

'English composition and English poetry'.

'You won't find much poetry about this place, I'm afraid. You don't know anything about shorthand, of course?'

'A little.'

'What do you mean by a little. Can you take a speaker down?'

'If he's not too fast.'

'Well, we'll try. No time like the present. There's a pencil and a notebook there on the table.'

'You've got a knife? All right. Point the pencil on both sides for fear of accidents. We'll start when you are ready.' ${ }^{21}$ 


\section{Bias and impartiality}

At a time of passionate and often violent political activity, many journalists consciously tried to forge a profession, engaging with issues of bias and impartiality, while being employed by a politically aligned press. Journalists often saw themselves as both politically aligned in their private lives, engaging with political controversy, while protesting their impartiality in what they produced professionally. Dunlop, for instance, while insisting on his impartiality in covering events associated with repealing the Union, was also the author of five pamphlets written for the Irish Loyal and Patriotic Union, the political association of Unionists businessmen, academics and landowners, founded in May 1885 to organise resistance to Home Rule. ${ }^{22}$ In relation to one employment position, Dunlop declared that:

It was well known that my political views were not those of the conductors of the Freeman's Journal, but it was equally well known that whatever might be the views I entertained my employer could depend on my giving fair and impartial reports. ${ }^{23}$

And again, Dunlop recounts his experience on the Freeman's Journal and what was expected of him, as a reporter: 'My experience on that journal [the Freeman's Journal] at that period was, that its conductors desired that the members of the reporting staff should give unbiased reports. ${ }^{24}$ In fact, the only complaint Dunlop has against any newspaper he worked for, at least professionally, is against a newspaper with which he would have been closely aligned politically. It was when working for The Irish Times that he complains about the sub editors in a way instantly recognisable to any reporter today. His copy was changed, an act he clearly believes was contrary to correct professional behaviour. He was covering the murder of a land agent in the west of Ireland and saw, when he read his newspaper, that an addition had been made to his story. Clearly Dunlop viewed himself as a professional with his own reputation independent of the newspaper that employed him.

This is a very unusual course for a sub-editor to adopt; for although as long as journalism is conducted on the anonymous system, the editor or it may be the proprietor of the newspaper is the person responsible to the public for what appears in its columns, the writer being responsible only to his employer; yet when a representative of a newspaper is sent on a mission such as I was entrusted with on this occasion, his identity necessarily becomes known, all the more so in my case because I was well known in Loughrea, and, to a limited circle - to those from whom he has been acquiring information for example - he is looked upon as the responsible individual. ${ }^{25}$

Dunlop, as a Unionist, was not unique in working successfully for newspapers 
that hardly reflected his own politics. T. P. O'Connor, as noted previously, worked for the Protestant Saunders Weekly, while Arthur Malley, also an Irish Parliamentary Party MP, was able to move from the Unionist Sligo Star to the nationalist Sligo Champion. ${ }^{26}$ The veteran Fenian, John Devoy, a journalist in Chicago and New York, recounts in his memoir how editorial writers simply wrote to order and not necessarily from conviction. ${ }^{27}$ Writing about his fellow Fenian, William O'Donovan, who worked for The Irish Times, Devoy observed:

After his Spanish experience William O’Donovan returned to Dublin and became an editorial writer on The Irish Times. It is one of the anomalies of daily journalism in every country (including America), that the editorials are largely written by men who don't agree with the policy of the paper, but write to order. While William O'Donovan, a Fenian, was writing Tory editorials for The Irish Times, Jack Adams, Atheist, was doing the Catholic articles in the Freeman's Journal. O'Donovan and Adams used to meet at supper in the Ship Tavern in Abbey Street and have a good laugh over their articles, of which they didn't believe a word. ${ }^{28}$

While political passions might sometimes test it, there is no doubt that by the 1870s, regardless of the political affiliations of the newspapers that employed them, reporters had developed a sense of professional solidarity.

\section{Journalism as a profession}

By the end of the nineteenth century, Irish journalists displayed traits that would indicate a growing professional consciousness. They had a skill in shorthand, a professional adherence to impartiality, and were aware of new developments within journalism, such as the interview, a new form of writing that was becoming increasingly popular.

My idea of what an interview should be, if the matter is one of a controversial nature, is that the interviewer should place himself in antagonism to the interviewed, so that the points in controversy may be clearly brought out, and fully discussed. Only in this way can the truth be elicited, and the merits or demerits of each side exhibited. ${ }^{29}$

Irish journalists had a clear view of themselves as a distinct category of workers. They joined the Institute of Journalists, in great numbers and exhibited solidarity with each other but as long time journalist, J. B. Hall observed:

It has often impressed itself on me during my elongated experience that reporters are apt at times to overlook the peculiarly and, indeed, 
exceptionally important and responsible position which they occupy, and have a tendency to put up with indignities which are possibly the result of this same want of self assertion. Too often they forget that as representatives of the Press they are entitled to be regarded as the most important arbiters of the situation in which their profession places them. ${ }^{30}$

A recognisable workplace organisation had also emerged, with similar practices and even its own jargon. Terms such as 'morning town' and 'night town', denoting particular work shifts, are still in use in newsrooms today. Bodkin, commenting on a typical, if rather idealised, day in the Freeman's Journal, which, he says could be applied to any Dublin newspaper of the day. ${ }^{31}$

In the Freeman's Journal, as in every well-regulated Irish newspaper office, there is a chief reporter, whose duty it is to set tasks to the rest. He knows, in his own expressive phrase 'what's on'. He keeps a record of all public proceedings. He has an instinct for news. Each morning the reporters meet the Chief in the reporters' room, are duly 'marked' in a Doomsday Book, for their respective tasks, and are dispatched through the city and country on their news gathering missions. Wherever there is anything interesting to be seen or heard the reporter is there, nothing escapes his all-pervading activity. He writes for a busy and curious public not a word too few, not a word too many, so that he who runs (for tram or train) may read and understand. ${ }^{32}$

From the middle of the nineteenth century, journalists in Ireland had forged a professionalism based on concepts of impartial reporting, common skills and membership of a professional body. Such were deemed necessary to ensure employment in a small media market. Journalists could move from newspaper to newspaper, regardless of the editorial line, or ownership. In other words impartiality had become an economic necessity, ensuring employment regardless of one's religion or politics, and allowed journalists to move from nationalist to unionist newspapers without a crisis of conscience.

The number of journalists engaged in politics was substantial. At one time the Irish Parliamentary Party in Westminster had more journalists within its elected ranks than any other political party, rising from one in 1880 to 15 in 1895. And of course, politically engaged journalists also worked outside Westminster: John Devoy, Joseph Clarke, Edmund O'Donovan, Arthur Griffith and Bulmer Hobson. Patrick Pearse and James Connolly, the two leaders of the 1916 Easter Rising, were also, at various times, journalists and editors.

By the 1890s and the first years of the twentieth century, great changes were beginning to take place and factors such as the growing influence of 
republicanism, the Irish Republican Brotherhood and other physical force movements, with their clandestine press, and the damage done to the Irish Parliamentary Party by the Parnell split, had implications for the Irish media. The Freeman's Journal suffered from the split in the IPP at Westminster. It had, from the 1890s, become an instrument of party policy, but managed to limp along for another two decades until finally absorbed by its rival, the Irish Independent, in 1924.

The merging of a number of newspapers associated with the Irish Parliamentary Party or Parnell, including the United Ireland, ${ }^{33}$ resulted in the businessman, William Martin Murphy, buying the Irish Independent which he re-launched in 1905. He had looked towards the popular journalism of Lord Northcliffe for his inspiration and sent his editor, T. R. Harrington, to London to study the popular press. Murphy had his own political views and was not afraid to use his newspapers to express them, particularly as the employers' leader during the great labour dispute, the Dublin Lockout of 1913. However, there is no doubt that his entry into the newspaper industry meant the slow end of the dominance of a political press in Ireland. As Ireland entered the twentieth century, and with independence from Britain in 1922, the newspaper market was comprised of The Irish Times representing the Protestant and still mainly Unionist population, and the Catholic middle classes represented by the conservative nationalist Irish Independent, and its sister newspapers. A range of small, often clandestine newspapers served the more radical republican tradition that would have to wait until 1931 for a national offering when Eamon de Valera founded the Irish Press. The Freeman's Journal limped along until 1924, when it was incorporated into the Irish Independent. It had found itself out of step with a more radical nationalism, following the collapse of the Irish Parliamentary Party in 1918, and also found itself unable to compete with William Martin Murphy's Irish Independent.

\section{Conclusion}

As Ireland shifted from a colonial to a post-colonial society, the growing professionalisation of journalists, with their sense of solidarity, a common ideology in impartial reporting, along with a professional confidence as displayed in various journalistic memoirs, meant they were well placed to make the transition from being a politically engaged group of workers to a professional group working for a post-colonial, less politically aligned press, one more concerned with nation building.

Irish journalists were influenced by debates about freedom of expression and the press and democracy that had been part of British and European discourse and adapted them to Ireland's colonial situation. If Britain was reluctant to extend a tolerance of the press to Ireland, the Act of Union made 
it difficult to apply a double standard with any consistency. This allowed journalists to work within and contribute to an embryonic public sphere and a growing civil society, which led to a democratic culture that was the result of reporting events, whether it was O'Connell's monster meetings, the activities of the Irish parliamentarians, the Land League, the co operative movement, cultural developments, or the Gaelic League and other areas of civic engagement.

The size of the Irish media, its role as a creator of public opinion and the need to develop a labour market, meant the journalist, however politically engaged, used such concepts as impartiality as a protection against being the victim of political and editorial change, and as a means of selling his labour to as wide a market as possible. It could also be argued that to adopt objectivity was itself a radical position in a colonial context, in that it set journalists in opposition to a state whose actions, whether in legislation or within institutions such as the courts of law would rarely be viewed as legitimate. The act of being 'objective' might itself be viewed as being partisan, in that it allowed the nationalist press to remain adversarial by simply not legitimising the colonial state.

Following Irish independence, the political role of the journalist shifted, becoming one of nation building and giving credibility to the new state. Even the pro- unionist Irish Times adopted the official names of the institutions of the new State, such as Taoiseach, for Prime Minister and the Dail, for parliament. In a similar vein, the Irish Press - founded by de Valera, to give support to his new constitutional political party, Fianna Fail - was forced to plough a delicate furrow between partisanship and professional norms, well aware that to fall too far on either side would threaten the credibility of the new venture. But by this time, the professionalised journalist was now well placed to play a legitimising function within a post-colonial Ireland.

\section{Notes}

1 J. K. Chalaby, The Invention of Journalism (London: Macmillan, 1998), p. 3.

2 J. Curran and J. Seaton, Power Without Responsibility: The Press and Broadcasting in Britain (London: Routledge, 1997). Curran and Seaton argue that far from the traditional Whig view of press history, a political press and the repression that went with it gave way to an increasingly commercial press funded by advertising. This, they argue, was far more effective in ridding Britain of its radical political press than censorship and repression.

3 To suggest the British press had become a commercial press is not to suggest it was non-ideological, but simply that it tended to support the status quo and reflected minor differences within that. The Irish press, on the other hand, reflected the fundamental divisions within a colonial society.

4 A. Dunlop, Fifty Years of Irish Journalism (Dublin: Hanna \& Neale, 1911), p. 62.

5 Illustrated London News, 25 December 1886. 
6 F. F. Moore, A Journalist's Notebook (London: Hutchinson, 1895), p. 220.

7 J. Leerson, Hidden Ireland, Public Sphere (Dublin: Arlene House, 2002), pp. 37-8.

8 R. Foster, Modern Ireland 1600-1972 (London: Allen Lane, 1988), p. 299.

9 M. L. Legg, Newspapers and Nationalism: The Irish Provincial Press, 1850-1892 (Dublin: Four Courts Press, 1999), p. 40.

10 B. Kissane, Explaining Irish Democracy (Dublin: University College Press, 2002), p. 113.

11 J. Horgan, Irish Media: A Critical History since 1922 (London: Routledge, 2001), p. 6.

12 Thackerary's Pendennis, introduces Captain Charles Shandon, the editor of the fictious Pall Mall Gazette: 'He was one of the wittiest, the most amiable and the most incorrigible of Irishmen.' Shandon was based on William Maginn, a brilliant but hard drinking Corkman who was a writer for the Standard.'

13 The provision of university education was a highly controversial issue throughout the late nineteenth century. In 1845, Parliament passed the Colleges Act, which established the Queen's Colleges in Belfast, Cork and Galway. They were condemned as 'Godless' by the Catholic hierarchy. Later a Catholic college was founded in Dublin, by Papal authority, but it could not confer degrees. In 1908, the National University was established with colleges in Dublin, Galway and Cork.

14 M. L. Legg, p. 23.

15 D. Kiberd, Irish Classics (London: Granta, 2000), p. 464.

16 M. Bodkin, Recollections of an Irish Judge: Press, Bar and Parliament (London: Hurst and Blackett, 1914), p. 26.

17 T. P. O'Connor was the only member of the Irish Parliamentary Party to sit at Westminster for an English constituency. As well as working as a journalist and editor, he was one of the founders of the so called New Journalism, see T. P. O'Connor, 'The New Journalism', The New Review, October 1889, pp. 423-34.

18 H. Fyfe, T. P. O'Connor (London: George Allen \& Unwin, 1934), p. 25.

19 Ibid., p. 25.

20 The real editor of the Freeman's Journal was Sir John Gray. Bodkin worked as a journalist for the Journal. In his novel the fictitious newspaper is called The Free Press, and the editor is John Grayle.

21 M. Bodkin, p. 129.

22 A. Dunlop, p. 121.

23 Ibid., p. 46.

24 Ibid., p. 46.

25 Ibid., p. 180.

26 I am indebted to Dr Mark Wehrly for information concerning newspapers in Sligo and Arthur Malley provided in an unpublished conference paper to the $2^{\text {nd }}$ annual conference of the Newspaper and Periodical History Forum of Ireland, at Dublin Institute of Technology, November 2009.

27 Fenians, a militant nationalist movement founded in New York by John 
O'Mahony in 1858, linked to the Irish Republican Brotherhood (IRB) a militant, secret organisation in Ireland.

28 J. Devoy, Recollections of an Irish Rebel (New York: McGlinchy, 1969 edn), p. 370.

29 A. Dunlop, p. 233.

30 J. B. Hall, Random Records of a Reporter (Dublin: Fodhla Press, 1929), p. 164.

31 What is remarkable is that such names are still used in Dublin newsrooms today.

32 M. Bodkin, pp. 28-9.

33 United Ireland, founded by Parnell in 1881, had as its first editor, William O’Brien. 